\title{
IL6R Gene
}

National Cancer Institute

\section{Source}

National Cancer Institute. IL6R Gene. NCI Thesaurus. Code C38920.

This gene in involved in the regulation of cellular responses; such as the immune response, hematopoiesis, and acute-phase inflammatory reactions. 